\title{
Literature Quizzes \\ Celebrating the Ongoing Importance of Wide Reading
}

\author{
Gerri Judkins \\ Southwell School \\ P O Box 14015 Hamilton \\ New Zealand \\ gerri.judkins@southwell.school.nz
}

\section{Literature Quizzes \\ Celebrating the Ongoing Importance of Wide Reading}

Literature Quizzes are an integral part of the Southwell School Library programme. Students read widely, hoping to represent us in the annual Kids' Lit Quiz ${ }_{T M}$ (www.kidslitquiz.com ). In this time of electronic entertainment entice your students to enjoy literature, books and ebooks. Reading encourages empathy with others whose lives and situations differ, global awareness, and knowledge of history. Myths and legends influence cultural practice and social realism helps them cope with life's problems. Reading is a resource for our humanity. At this workshop play brain-training games. These will be given away along with signed books from New Zealand authors. Learn how to write quiz questions and select teams. Hear how we use cognitive technology to help students retain and retrieve literary information. Make Lit Quizzes part of your library programmes and see your readers grow exponentially. There may be a regional of the Kids' Lit Quiz ${ }_{T M}$ near you!

Keywords: Literature, Quizzes, Wide Reading

\section{Literature Quizzes - Celebrating Wide Reading}

This Workshop includes a visual Power Point and a lot of interaction with participants including literary games, learning activities and a quiz. What follows is an explanation of the workshop's context.

Southwell School in Hamilton, New Zealand was founded in 1911 with three male students. Girls were included in 2000 and there are now 620 students aged 5-12. In my $17^{\text {th }}$ year at Southwell, I am now job sharing $(70 \% / 30 \%)$ with Julie Huggins who has also been working with Lit Quiz teams for the same length of time. Resources made by her will be credited on the Power Point shown at the workshop.

Literature Quizzes are an integral part of the Southwell School Library programme. We have Junior and Senior Inter House Lit Quizzes in Book Week, a Lit Club and 'Super Keen Readers' who train with hopes of representing Southwell in the annual regional of the Kids' Lit Quiz ${ }_{\mathrm{TM}}$. Just what is the Kids' Lit Quiz ${ }_{\mathrm{TM}}$ and why is it trademarked? 
Twenty-three years ago when University lecturer Wayne Mills' children were at school he saw students getting awards for Maths and Science and Sport. But where, he asked himself, were the awards for reading? In 1991, with the help of the Waikato Children's Literature Association he organized the first lit quiz for Hamilton school children in Year 7 \& 8 (11-12 year olds). It is now known as the International Sport of Reading with heats and national finals this year in New Zealand, the United Kingdom, South Africa, Canada, USA, China, Hong Kong, Singapore and Australia. National winners qualify for the World Finals which, in 2014, are in Truro, Cornwall, England.

Because he considers the many thousands of questions he has written and the particular format of his quiz his intellectual property, Wayne has trademarked it. So, in consideration of this, our quizzes at Southwell are a little different and we write our own hundreds of questions.

Now, over 4,000 $10-13$ year olds take part in the New Zealand regional Kids' Lit Quiz $\mathrm{TM}_{\mathrm{T}}$ competitions annually. Last year thirteen teams went on to Nationals and the team from Takapuna Normal Intermediate in Auckland represented NZ in the World Final in Durban placing $2^{\text {nd }}$. Four New Zealand readers go on to the World Final. For the thousands of others it is all about the journey - a journey that inspires them to become lifelong readers.

The New Zealand singer Lorde, Ella Yelich, has taken the world by storm. She was a Lit Quiz kid from Belmont Intermediate in Auckland. In 2008 her team were runners up in the Nationals and winners in 2009. They went on to place $2^{\text {nd }}$ in the South African World Final. Wayne said at that stage Ella was reading a book a day. Lorde is the song writer reading made!

\section{The Regional Quiz}

One or two teams of four $10-13$ year olds, representing local schools, participate in a written quiz. This is scored round by round to the mounting excitement of the teams. There are ten rounds of ten questions in a variety of categories, which are unknown prior to the quiz. There is one visual category and teams choose a double points round. Questions can be about any author or illustrator, any book suitable for children, ever written in the English language from myths, legends and the Bible to contemporary fiction. Categories in the 2014 Waikato Quiz included Cannibals, Famous Animals, Colours, Wings, Super Heroes and Time. Some questions are easy to ensure all celebrate success, others are difficult indeed. It was a delight that with 45 teams competing, this year Southwell placed $1^{\text {st }}$ and $2^{\text {nd }}$. The 14 regional winners compete in the 10 June National, yet to happen as I write this.

Preparation for the regionals requires very wide reading. Along with the popular contemporary fiction (especially dystopian) the students need to be familiar with fables, classics, myths and legends, folk talks and fairy tales, poetry, comics, authors and illustrators. This wide reading leads to an appreciation of literary reference in books like Chris Riddell's Goth Girl and the Ghost of a Mouse where Ada's nannies included Jane Ear, Becky Sharp, Hebe Poppins and Nanny Darling. Those familiar with Greek mythology have a better understanding of the characters in books like Rick Riordan's Percy Jackson and the Lightning Thief, Diana Wynne Jones' The Game, Kate O'Hearn's Pegasus and the Flame and The Goddess Test by Aimee Carter. 


\section{Gathering Enthusiasts}

Southwell has a non-competitive Lit Club that meets to share a love of reading, has a hand in choosing books for the library, runs the Junior Lit Quiz in Book Week and hosts visiting authors and illustrators.

We put out an "open casting call" for those keen to try out for a place in one of the competitive teams. We have fun with the initial group, playing games and running preliminary quick quizzes endeavouring to grow the knowledge. We then cull the group with a selection quiz, direct learning and have, yet more fun.

We track for the best fit team. In a documentary on the Cambridge University Rowing Team, the coach said "The four best may not be the best four". A powerful team needs children with a range of strengths. Every mini quiz is recorded on a grid, colour coded for each member of the group. Blocks of colour denote knowledge and an increase in colour density growth. A Chinese child, not raised with European nursery rhymes, initially scored 1/10 then five months later in a similar quiz got 19.5/20. In the earlier quiz no one knew the number of fiddlers Old King Cole had - a leaning opportunity. Students record their reading on a Google Doc and we develop another one, with authors' biographical information.

\section{Student Research}

As a homework project, students make posters with the background of a city or country featuring the covers of books set there. Examples to be shown are: Paris with Madeline and The Invention of Hugo Cabret; Venice with The Thief Lord and City of Masks and Afghanistan with Parvana, Parvana's Journey and Shadow. They also gather stamps in a Read Your Way Around The World Passport and read stories from the past and about possible futures, to enter in a Time Travellers' Passport.

\section{Stations and Games}

As well as meeting weekly at the start of the year, there are two evening sessions that allow us more time to train teams for the May regional. Stations are activities such as identifying a range of comic characters, recognising fables from illustrations and knowing their morals, being able to complete nursery rhyme lines and fill in the gaps of authors, titles, characters and settings on a Classics Sheet. Workshop participants will do these activities and consider what similar tasks would be relevant to the literature of their countries.

We use a Memory game to help students match cards and identify illustrators and creatures of myth and legend. Pictionary is a great hit and the clue cards used with Characters Titles, Nursery Rhymes and Mythical Creatures will be given away. Taboo will be next and we'll see who can describe a character or title without saying any of the forbidden words! Both of these literary versions were adapted by Julie Huggins.

\section{National Quiz and World Finals}

This will be the fourth time Southwell has been to the National Quiz. It is a very different style of competition. Each team starts with 10 points. As Wayne reads the questions, the first team to press their buzzer has a chance to answer. Correct and you gain 2 points, wrong and you lose 1. There is a category of first lines and 'Who is this author/illustrator'. So, we drip feed the team members five first lines and information about three authors or illustrators each night in the time between our regional and the national competition. 
In 2009 The Waikato Children's Literature Association was asked to host the 2001 World Final - or $20^{\text {th }}$ Anniversary International Final, as it was called that year. Southwell kindly gave us use of the buildings (including Boarding House) free of charge. A lot of fund raising was required to cover the week's expenses, including days of tourism, for the teams from Canada, Britain (two teams), South Africa and the NZ Champions. There was 'fun raising' too. Each team had a local 'buddy school' who entertained them for a day, cheered for them at the Quiz and came to the Gala Dinner where New Zealand authors, Tessa Duder, David Hill, Brian Falkner and Jenny Hessell talked about their work. Lasting friendships were formed and two of the children, one from South Africa and the other from New Zealand, will meet up again this year.

\section{Book Week Quizzes}

The Southwell Book Week features a Junior and Senior Inter House Lit Quiz. This year, by request from ex Lit Quiz kids who missed the sport of reading, Julie and I included a High School Quiz. Many of our past pupils participated and there were three in the winning team. This quiz was such a success it will now be an annual event. Some of the students went off with the intention of running one themselves for their school, just as we'd hoped.

Now Julie and I can enjoy even more YA fiction at the upper end! I just finished John Green's Paper Towns which leads readers to S. E. Hinton's The Outsiders and Walt Whitman's Leaves of Grass.

\section{Lit Quizzes at IASL Schools}

Workshop participants will be asked to think how Lit Quizzes could fit into their reading programmes and their educational community. They will be encouraged to consider quiz writing, making resources and taking the fun home.

\section{Moscow IASL Lit Quiz}

In the time available at the end of the workshop a Mini Quiz will held with bookmark prizes. Finally, names will be drawn for signed copies of New Zealand children's books.

\section{References}

Bemelmans, L. (1967). Madeline. New York: Viking Press.

Carter, A. (2011). The Goddess Test. North Sydney, NSW: Harlequin Teen.

Ellis, D. (2002). Parvana. Crows Nest, NSW: Allen \& Unwin.

Ellis, D. (2002). Parvana’s Journey. East Melbourne, Vic: Allen \& Unwin.

Funke, C. (2002). The Thief Lord. New York: Scholastic.

Green, J. (2008). Paper Towns. New York: Dutton Books.

Hinton, S. E. (2006). The Outsiders. New York: Speak.

Hoffman, M. (2008). City of Masks. London: Bloomsbury.

Jones, D. W. (2008). The Game. London: Harper Collins Children's Books.

Morpurgo, M. (2010). Shadow. London: Harper Collins Children's Books. 
O'Hearn, K. (2011). Pegasus and the Flame. London: Hodder Children's.

Riddell, C. (2013). Goth Girl and the Ghost of a Mouse. London: MacMillan Children's Books. Riordan, R. (2010). Percy Jackson and the Lightning Thief. London: Puffin.

Selznick, B. (2007). The Invention of Hugo Cabret. New York: Scholastic Press.

Whitman, W. (1950). Leaves of Grass and Selected Prose. New York: The Modern Library.

\section{Biographical note}

Gerri Judkins is librarian at Southwell School in Hamilton. A member of SLANZA (School Library Association of NZ Aotearoa), she served on the National Executive, has presented at five SLANZA conferences and is secretary of the Waikato Children's Literature Association.

In 2012 she received the Storylines Betty Gilderdale Award for services to Children's Literature (http://www.storylines.org.nz/Awards/Betty+Gilderdale+Award.html) and in 2014, an Independent Schools of NZ Honour Award for Service to Literature and Library (http://www.isnz.org.nz/awardsboard).

On the ISLM Committee, she organizes translations of the ISLM theme and the Skype Exchange and presented at IASL conferences in 2009 and 2010. 